\title{
Resenha
}

\section{As Ilusões Inerentes aos Direitos Humanos}

CHAUÍ, Marilena; SANTOS, Boaventura de Sousa. Direitos humanos, democracia e desenvolvimento. São Paulo: Cortez, 2013.

\section{Kelma Lima Cardoso Leite}

Formada em Ciências Sociais pela Universidade Federal do Ceará. Mestrado e doutorado obtido no Programa de Pós-Graduação em Sociologia da Universidade Federal do Ceará. kelma.leite@hotmail.com

Recebido em: 13/5/2017

Aceito em: 20/5/2017

Redigido a partir do seu discurso de aceitação do título de doutor honoris causa pela Universidade de Brasília, o livro do professor português Boaventura de Sousa Santos intitulado Direitos Humanos, Democracia e Desenvolvimento, apresenta um prefácio do professor José Geraldo Sousa Júnior, então reitor na UnB, e uma sucinta apresentação realizada pela coautora da obra, a filósofa Marilena Chauí. A obra supracitada foi dividia pelo autor em dois capitulos e uma resumida conclusão.

O proeminente estudioso dos direitos humanos, respeitado no meio jurídico brasileiro e internacional, inicia sua discussão convidando à reflexão acerca do paradoxo entre o discurso hegemônico dos direitos humanos e a realidade perturbadora de milhares de pessoas no mundo 
que constituem os não sujeitos de direitos humanos. Daí, segundo ele, a necessidade de se perguntar: "Será a hegemonia de que goza hoje o discurso dos direitos humanos o resultado de uma vitória histórica ou, pelo contrário, de uma derrota histórica?”

$\mathrm{O}$ autor reconhece que a linguagem hegemônica da dignidade humana é oriunda da mesma hegemonia que consolida e legitima a opressão de grupos sociais oprimidos. Logo, é mister saber se os direitos humanos poderão ser usados para disturbar tal intrínseca relação. Boaventura de Sousa Santos conduz ainda o leitor a problematizar os direitos humanos a partir de uma série de inquietantes indagações: "Poderão os direitos humanos serem usados de modo contra-hegemônico? Por que há tanto sofrimento humano injusto que não é considerado uma violação dos direitos humanos? Que outras linguagens de dignidade humana existem no mundo?”

O empreendimento investido na tentativa de responder a tais questionamentos exigiu do referido teórico e pesquisador uma postura definida por ele mesmo como hermenêutica de suspeita, que suscita uma reflexão crítica da concepção convencionalmente construída pela matriz liberal ocidental. Para começar, ele recupera historicamente a genealogia dos direitos e do Direito na modernidade ocidental. O sociólogo português afirma conceber as versões dominantes da modernidade ocidental como balizadas num pensamento abissal que dividiu o mundo entre sociedades metropolitanas e coloniais.

Nesse sentido, a versão hegemônica do Direito e dos direitos humanos metropolitanos sobrepõem-se à realidade concreta das colônias a ponto de as tornarem invisíveis. Assim, essa linha abissal acaba por recrudescer e garantir a continuidade de exclusões radicais, mesmo após o fim do colonialismo histórico, sob diferentes formas: neocolonialismo, racismo, xenofobia, permanente estado de exceção na relação com terro- 
ristas, trabalhadores imigrantes indocumentados, candidatos a asilo ou mesmo cidadãos comuns vítimas de políticas de austeridade ditadas pelo capital financeiro.

Por outro lado, Boaventura de Sousa Santos assegura que não podemos perder de vista a genealogia revolucionária do Direito e dos direitos humanos no reduto colonial, afinal, tanto a Revolução Americana como a Revolução Francesa foram realizadas em nome da lei e do direito da maioria. Não obstante, o autor salienta ainda que no contexto de tais revoluções tanto o conceito de lei como de Direito adequavam-se aos propósitos do individualismo burguês emergente que depois de conquistar a hegemonia econômica almejava também a hegemonia política.

Devido à influência ideológica dos propósitos burgueses, o sociólogo lusitano afirma que a ideia de que a evolução dos direitos humanos seguiu historicamente um percurso linear regido por princípios reguladores de uma sociedade mais justa reflete algumas ilusões que constituem o senso comum dos direitos humanos convencionais: a teleologia, o triunfalismo, a descontextualização, o monolitismo e o antiestatismo.

A ilusão teleológica impossibilita perceber que o presente, assim como o passado, é contingente, ou seja, em cada contexto histórico díspares ideias estiveram em constante competição e que o triunfo de uma ou de outra, em particular dos direitos humanos, é uma reverberação contingencial que pode ser explicada $a$ posteriori, mas que não deveria ser deterministicamente prevista.

A segunda ilusão, batizada de triunfalismo, fundamenta-se na ideia de que a vitória dos direitos humanos é um bem humano incondicional. Sousa Santos, todavia, lembra que o fato de outras linguagens de emancipação social - como o socialismo e o comunismo - terem sido sobrepujadas pelos direitos humanos só poderá ser declarado intrinsecamente 
positivo se se constatar que os direitos humanos possuem um mérito, como linguagem de emancipação, independentemente de ter sido a linguagem vencedora.

Ciente disso, é possível problematizar a terceira ilusão, a saber, a descontextualização. Segundo nosso autor, é do conhecimento de muitos que os direitos humanos, como linguagem emancipatória, são oriundos do Iluminismo do século 18 , mais precisamente do contexto revolucionário francês e americano. É preciso atentar, no entanto, que desde então os direitos humanos foram e continuam sendo usados como discurso e arma política em contextos bastante controversos. Nesse sentido, a linguagem dos direitos humanos historicamente baliza e legitima práticas consideradas opressivas e até mesmo contrarrevolucionárias.

A quarta ilusão, denominada monolitismo, restringe-se a negar ou minimizar as tensões e contradições internas das teorias dos direitos humanos. $\mathrm{O}$ fato é que apesar de os direitos humanos ao longo dos últimos 200 anos terem sido incorporados nas constituições e práticas jurídico-políticas de muitos Estados-nação, a efetividade concreta da proteção profusa dos direitos de cidadania, por exemplo, tem se mantido precária na maioria dos países.

A quinta ilusão, definida como antiestatismo, emergiu historicamente na modernidade ocidental suscitado pelo bifronte processo de secularização e de individualização que traduz social e politicamente um posicionamento do Terceiro Setor contra o Estado absolutista constituído pela nobreza e o clero. Este processo cristalizou a ideia de que os direitos humanos para serem respeitados necessitavam de uma abstenção do Estado em agir de maneira interpretada recorrentemente como violador dos direitos.

Para Sousa Santos, ter em mente estas ilusões é fulcral para construir uma concepção e uma prática contra-hegemônica de direitos humanos que coadune com o trabalho político dos movimentos e organizações 
sociais que travam uma batalha precípua em prol de uma sociedade concretamente mais justa e digna. Ao mesmo tempo, a ciência destas ilusões permitirá uma construção alternativa de direitos humanos capaz de desconstruir a teoria ambígua que baliza o consenso de que gozam os direitos humanos na atualidade. A proposta de Boaventura de Sousa Santos em Direitos Humanos, Democracia e Desenvolvimento é questionar os direitos humanos e todos os que os exploram para elucidar e modificar o mundo com a seguinte interrogação: "De que lado estão eles? Do lado dos oprimidos ou do lado dos opressores?”

Destarte, os esforços do sociólogo português na supracitada obra têm por objetivo uma reconstrução teórica e política dos direitos humanos. Para isso ele faz referência às lutas nos contextos brasileiro e mundial que podem corroborar para uma reflexão crítica profícua. Nesse sentido, o autor organiza os seus argumentos analisando de maneira sucinta algumas das principais tensões que perpassam as lutas políticas construídas por referência aos direitos humanos: a tensão entre o universal e o fundacional; a tensão entre direitos individuais e direitos coletivos; a tensão entre o Estado e o anti-Estado; a tensão entre secularismo e pós-secularismo; a tensão entre direitos humanos e deveres humanos; a tensão entre a razão de Estado e a razão dos direitos; a tensão entre o humano e o não humano; a tensão entre o reconhecimento da igualdade e o reconhecimento da diferença; a tensão entre o direito ao desenvolvimento e outros direitos humanos individuais e coletivos, nomeadamente o direito à autodeterminação, o direito a um ambiente saudável, o direito à terra e o direito à saúde; a tensão entre o direito ao desenvolvimento e os direitos ambientais e em especial o direito à saúde; a tensão entre a autodeterminação indígena e o desenvolvimento neoliberal; a tensão com os direitos dos povos de se libertarem do colonialismo e do neocolonialismo. 
Enfim, a leitura e análise da obra Direitos Humanos, Democracia e Desenvolvimento permite perceber duas questões importantes. Primero, que a luta pelos direitos humanos nestas duas décadas do século 21 enfrenta novas formas de autoritarismo que coabitam com regimes democráticos. Segundo, que o fascismo desenvolvimentista continua a influenciar os Estados e governos ditos democráticos a fazer tábua rasa dos direitos de cidadania e humanos ao mesmo tempo que reprimem de maneira brutal todos aqueles que ousam resistir-lhe. 